\title{
QTc and psychopharmacs: are there any differences between monotherapy and polytherapy Jadranka Čulav Sumić* ${ }^{*}$ Vesna Barićł, Petar Bilić ${ }^{\prime}$, Miroslav Herceg ${ }^{\dagger}$, Mirna Sisek-Šprem ${ }^{\dagger}$ and Vlado Jukić ${ }^{\dagger}$
}

Address: Vrapče Psychiatric Hospital, Bolnička 32, 10090 Zagreb, Croatia

Email: Jadranka Čulav Sumić* - damir_sumic@yahoo.com; Vesna Barić - vesna.baric@bolnica-vrapce.hr; Petar Bilić - petar.bilic2@zg.t-com.hr; Miroslav Herceg - miroslav.herceg@bolnica-vrapce.hr; Mirna Sisek-Šprem - mirna.sisek-sprem@bolnica-vrapce.hr;

Vlado Jukić - vlado.jukic@bolnica-vrapce.hr

* Corresponding author †Equal contributors

Published: 3 May 2007

Annals of General Psychiatry 2007, 6:13 doi:10.1186/1744-859X-6-13
Received: 22 December 2006

Accepted: 3 May 2007

This article is available from: http://www.annals-general-psychiatry.com/content/6/I//3

(c) 2007 Sumić et al; licensee BioMed Central Ltd.

This is an Open Access article distributed under the terms of the Creative Commons Attribution License (http://creativecommons.org/licenses/by/2.0), which permits unrestricted use, distribution, and reproduction in any medium, provided the original work is properly cited.

\begin{abstract}
Background: Some psychotropic drugs are connected with prolongation of QT interval, increased risk of cardiac arrhythmias and greater incidence of sudden death, especially when used in combination. Concomitant use of antipsychotics and antidepressants is not rare in our clinical practice. The study compares the length of QT interval in patients on monotherapy with an antipsychotic or an antidepressant and patients taking polytherapy (an antipsychotic agent combined with an antidepressant).

Methods: Sixty-one hospitalized women who met the ICD-10 criteria for schizophrenia, schizoaffective psychosis, delusional disorder and mood disorder were included in the study. The monotherapy group was consisted of thirty-two women treated with an antipsychotic or an antidepressant while the polytherapy group was composed of twenty-nine women treated with an antipsychotic agent plus an antidepressant. Two electrocardiograms (ECGs) were obtained for each patient: the first was carried out before the treatment and the second after two weeks of treatment.

Statistical analysis was carried out by SPSS program and included unpaired and paired $t$ test and Fisher's exact test.

Results: Mean baseline QTc values did not differ between the groups (439 $\pm 22 \mathrm{~ms}$ was the same value found in the both groups; unpaired t test, $p>0.5$ ). Mean QTc intervals after two weeks of treatment were also similar (439 $\pm 24 \mathrm{~ms}$ in the monotherapy group and $440 \pm 20 \mathrm{~ms}$ in the polytherapy group; unpaired $t$ test, $p>0.5)$. Fisher's exact test did not reveal significant difference in the number of patients with borderline $(45 \mathrm{I}-470 \mathrm{~ms})$ or prolonged $(>470 \mathrm{~ms})$ QTc between groups, neither before treatment nor after two weeks of treatment. Twenty two women of the total of sixty one patients (36\%) had QTc $>450$ ms before applying therapy.

Conclusion: We did not find significant QT prolongation in our patients after two weeks of treatment with antipsychotics and/or antidepressants. The QTc interval length did not differ significantly in the monotherapy and the polytherapy group. More than one third of included women exceeded the threshold value of borderline QTc interval $(450 \mathrm{~ms})$ before starting treatment. This finding calls for caution when prescribing drugs to female psychiatric patients, especially if they have other health problems.
\end{abstract}




\section{Background}

Psychotropic drugs are among medications connected with prolongation of the QT interval and greater occurrence of sudden cardiac death [1-7]. The QT interval is the sequence of the ECG from the beginning of the QRS complex to the end of the $\mathrm{T}$ wave and represents the temporal equivalent of ventricular depolarization and repolarization. Its value corrected for heart rate is referred as corrected QT interval (QTc). There is no consensus about the upper physiological limit for QTc [8]. European Medicines Agency quotes different possible upper values (450 $\mathrm{ms}, 480 \mathrm{~ms}$, and $500 \mathrm{~ms}$ ) and calls for caution when change from baseline exceeds 30-60 ms [9]. Significant QT prolongation ("long QT syndrome", LQTS), inherited or acquired, is associated with the increased susceptibility to ventricular tachyarrhythmia "torsade de pointes" (TdP) that either resolve spontaneously or deteriorate into ventricular fibrillation and sudden death. In comparison to men, women are at higher risk for developing TdP because the feminine gender is associated with a longer baseline QT interval, perhaps due to differences in circulating sex hormones [10-13]. For females, QTc interval values more than $450 \mathrm{~ms}$ are commonly used as borderline and those over $470 \mathrm{~ms}$ as prolonged [14-16].

Congenital forms of LQT syndrome are due to autosomal recessive (Jervell and Lange-Nielsen syndrome) or autosomal dominant (Romano-Ward syndrome) mutations of several genes encoding for cardiac ion channels with consequent disturbances in electrical activity of the heart [1722]. LQTS mutation carriers are present in one of 1000 to 3000 individuals [23].

Acquired long QT syndrome occurs when one or more risk factors, such as drugs that block certain cardiac ion channels, provoke a prolonged QT interval. Common causes of acquired LQTS are several classes of drugs, e.g. Class I and III antiarrhythmics, macrolides antibiotics, antihistamines, antipsychotics and antidepressants [24]. International Registry for Drug-Induced Arrhythmias by the University of Arizona [25] put some antipsychotics among the drugs with the most prominent arrhythmogenic activity (haloperidol, chlorpromazine, pimozide and thioridazine); less capable to induce arrhythmias are clozapine, lithium, quetiapine, risperidone, venlafaxine and ziprasidone. Antidepressants (amitriptyline, clomipramine, citalopram, fluoxetine, paroxetine and sertraline) are at lower risk if they are not combined with other risk factors known to prolong the QT interval (e.g. concomitant therapy with QTc prolonging drugs or inhibitors of cytochrome 450 enzymes, bradycardia, presence of congenital LQTS, and electrolyte imbalance like hypokalaemia and hypocalcaemia). Some studies pointed out the greater possibility for cardiac arrhythmias when antipsychotic drugs are combined with antidepressants [26].
Because concomitant use of antipsychotics and antidepressants are not infrequent in our clinical practice we decided to explore are there any differences in the length of QTc between patients on monotherapy with an antipsychotic or an antidepressant and patients treated with combination of these drugs (an antipsychotic plus an antidepressant).

\section{Methods}

A prospective investigation was performed in Psychiatric hospital Vrapče, Zagreb. Sixty one patients, all women, were included in the study, as consecutively received patients from January to September 2006. Informed consents were obtained and the local ethic committee approved the investigation. The patients met the ICD-10 (International Classification of Disease, $10^{\text {th }}$ revision) criteria for schizophrenia, schizoaffective psychosis, delusional disorder and mood disorder. According to patient's history, clinical examination and laboratory tests, patients with liver or renal disorders, cardiovascular disease or psychoactive drugs dependence were not included in the study. The use of depot-therapy in the month prior to investigation and the use of fluoxetine (because of its long half-life) were the exclusion criteria also.

The patients were free of drugs minimum 48 hours before the first ECG and the blood samples were taken. Only the use of lorazepam (up to $7.5 \mathrm{mg} / \mathrm{d}$ ) was permitted. The second ECG was carried out after two weeks of treatment. The group 1 was on monotherapy (treated with an antipsychotic or an antidepressant). The group 2 was on polytherapy (treated with an antipsychotic and an antidepressant). As concomitant therapy in both groups the use of biperiden or lorazepam was possible if necessary. All daily antipsychotic and antidepressant doses were converted to defined daily dose equivalents (DDD), as defined by the World Health Organization, and the current daily dose was categorized into less than one DDD equivalent and one or more DDD equivalents [27].

All patients had normal liver and renal functions according to normal values of transaminases, blood urea nitrogen and creatinine. The serum levels of potassium, sodium and calcium ions were determined. Body weight and height were measured and body mass index (BMI) was calculated. ECG was performed by routine clinically used 12-lead electrocardiogram apparatus which automatically calculates the QTc interval. We are aware that the method used is a limitation of this study because the measurement by the cardiologist could have been more accurate [28]. The length of QT interval was compared before and after treatment in the same group and between the groups; differences were statistically analysed. The statistical analysis was done using SPSS program 12.0 and 
included independent and dependent $t$ test and Fisher's exact test.

\section{Results and discussion Characteristics of patients and applied therapy}

Sixty one patients were included in the study. Thirty two women were receiving an antipsychotic or an antidepressant (group 1) and twenty nine women were treated with an antipsychotic in combination with an antidepressant. The two groups did not differ significantly with respect to age, duration of illness, BMI, smoking status and doses of psychopharmacs converted to DDD equivalents (Table $1)$. In twenty patients (33\%) doses of applied psychotropic drugs were above DDD while forty one patients $(67 \%)$ had equal or smaller doses in comparison to DDD. Table 2 show the frequency of applied antipsychotics and antidepressants respectively in the both groups.

\section{QTc interval}

Mean baseline values of QTc in group $1(439 \pm 22 \mathrm{~ms})$ and group $2(439 \pm 22 \mathrm{~ms})$ were similar (independent $\mathrm{t}$ test $\mathrm{p}$ $=0,953$ ) (Table 3). There were no significant differences in the length of QTc between the groups after two weeks of treatment also: the mean values were $439 \pm 24 \mathrm{~ms}$ in the group 1 and $440 \pm 20 \mathrm{~ms}$ in the group 2 (independent $\mathrm{t}$ test $\mathrm{p}=0,878$ (Table 3 ). In group 1 the length of QTC before and after treatment was similar (dependent $t$ test $\mathrm{p}$ $=0.989$ ); the same was observed in group 2 (dependent $t$ test $\mathrm{p}=0.812$ ). The two groups did not differ significantly in the number of patients with QTc $>470 \mathrm{~ms}$, not before therapy (Fisher's exact test $\mathrm{p}=0.600$ ) neither after two weeks of treatment (Fisher's exact test $\mathrm{p}=0.674$ ). There were three women $(9.4 \%)$ in the group 1 with the QTc prolongation more than $30 \mathrm{~ms}$ from the baseline value (prolongations were 30,32 , and $87 \mathrm{~ms}$ ) and the same number was found in the group $2(10.3 \%)$, (prolongations were 44,66 , and $66 \mathrm{~ms}$ ). Mean values of QTc pro- longation in the group 1 and group 2 were $8 \pm 17 \mathrm{~ms}$ and $9 \pm 19$ ms respectively (independent $t$ test $\mathrm{p}=0.840$ ).

Our study did not reveal significant differences in the mean QTc length between women treated with antipsychotics or antidepressants and women who were treated with both of these drugs. There was no significant QT prolongation after two weeks of treatment in the both groups too. No one patient had QTc $=500 \mathrm{~ms}$. Eight patients of sixty one patients included in the study (13\%) had QTc intervals $>470 \mathrm{~ms}$ and/or the QTc prolongation of $30 \mathrm{~ms}$ or more from the baseline value. Five of these eight patients were from the monotherapy group: three women who were taking fluphenazine $(7.5 \mathrm{mg} / \mathrm{d})$, venlafaxine $(37.5 \mathrm{mg} / \mathrm{d})$ or mirtazapine $(30 \mathrm{mg} / \mathrm{d})$ had hypocalcae$\mathrm{mia}$, one woman was on ziprasidone $(160 \mathrm{mg} / \mathrm{d})$ and the last one (on fluphenazine $7.5 \mathrm{mg} / \mathrm{d}$ ) had borderline QTc before starting treatment. The rest three patients were in the polytherapy group: one woman was treated with promazine $(200 \mathrm{mg} / \mathrm{d})$ and maprotiline $(100 \mathrm{mg} / \mathrm{d})$ and had positive family history of sudden father's death; one patient was on high antidepressant therapy: paroxetine $(40 \mathrm{mg} / \mathrm{d})$ in combination with mirtazapine $(30 \mathrm{mg} / \mathrm{d})$ and olanzapine $(5 \mathrm{mg} / \mathrm{d})$; the third one was treated with promazine $(75 \mathrm{mg} / \mathrm{d})$ and venlafaxine $(75 \mathrm{mg} / \mathrm{d})$. All of these eight patients had normal potassium and sodium serum levels.

One potential explanation why we did not observe significant QT prolongation in women on combined psychotropic therapy could be the dose of psychopharmacs applied. In two third of included patients doses of antipsychotics and antidepressants were equal or below DDD, in the group 1 and 2. The quantity of drug given to patient was determined by psychiatrist who cured the patient and was clinically determined. Further more, some authors point out that DDD equivalents are smaller than chlorpromazine or haloperidol equivalents used in some pre-

Table I: Characteristics of patients

\begin{tabular}{|c|c|c|c|}
\hline Characteristic & $\begin{array}{c}\text { Group I }(N=32) \\
\text { Patients in monotherapy }\end{array}$ & $\begin{array}{c}\text { Group } 2(N=29) \\
\text { Patients in polytherapy }\end{array}$ & $* \mathbf{p}$ \\
\hline Age, range $(y r)$ & $27-69$ & 27-70 & \\
\hline Age, mean \pm SD $(y r)$ & $48.3 \pm 8.8$ & $48.6 \pm 11.3$ & 0.771 \\
\hline Duration of illness, mean \pm SD $(y r)$ & $10.8 \pm 7.3$ & $10.7 \pm 9.1$ & 0.950 \\
\hline $\mathrm{BMI}$, mean $\pm \mathrm{SD}$ & $25.1 \pm 5.5$ & $27.9 \pm 5.5$ & $\begin{array}{c}0.059 \\
* * \mathrm{p}\end{array}$ \\
\hline Smoking present, N (\%) & $16(50.0)$ & $15(5 \mathrm{I} .7)$ & 1.000 \\
\hline \multicolumn{4}{|l|}{ Applied dose > DDD: } \\
\hline Dose of AP > DDD, N (\%) & $7(21.9)$ & $8(27.6)$ & 0.767 \\
\hline Dose of AD > DDD, N (\%) & $9(28.1)$ & II (37.9) & 0.586 \\
\hline
\end{tabular}

*p - 2-tailed $\mathrm{t}$ test; **p - 2-tailed Fisher Exact test; BMI - "body mass index";

DDD - "defined daily dose"; AP - antipsychotic; AD - antidepressant 
Table 2: Characteristics of applied therapy

\begin{tabular}{|c|c|c|c|c|c|}
\hline \multirow{2}{*}{ Psychotropic drug } & \multicolumn{2}{|c|}{$\begin{array}{c}\text { Group I (N=32) } \\
\text { Patients in monotherapy }\end{array}$} & \multicolumn{3}{|c|}{$\begin{array}{c}\text { Group } 2(N=29) \\
\text { Patients in polytherapy }\end{array}$} \\
\hline & \multirow[t]{2}{*}{$N$ of patients } & \multirow[t]{2}{*}{ dose range $(\mathrm{mg} / \mathrm{d})$} & \multirow[t]{2}{*}{$N$ of patients } & \multirow[t]{2}{*}{ dose range $(\mathrm{mg} / \mathrm{d})$} & \\
\hline & & & & & $A D$ used \\
\hline \multicolumn{6}{|l|}{ Antipsychotic } \\
\hline Ziprasidone & 3 & $120-160$ & 1 & 120 & map \\
\hline Olanzapine & 4 & $10-20$ & 7 & $5-15$ & Mir,ven,par,fluo \\
\hline Clozapine & 1 & 100 & - & - & - \\
\hline Risperidone & 3 & $3-5$ & 1 & 4 & map \\
\hline Sulpiride & I & 400 & 3 & $50-200$ & ser,clo \\
\hline fluophenazine & 7 & $5-8$ & 6 & $2-15$ & tia,ser,par,map \\
\hline Haloperidol & 3 & $6-15$ & 4 & $4-15$ & mir,map,esc,clo \\
\hline Promazine & - & - & 4 & $75-350$ & tia,ven,map \\
\hline Quetiapine & - & - & 2 & $300-500$ & par,fluo \\
\hline \multirow[t]{2}{*}{ zuclopenthixol } & - & - & I & 10 & Fluo \\
\hline & & & & & \multirow[t]{2}{*}{$A P$ used } \\
\hline \multicolumn{5}{|l|}{ Antidepressant } & \\
\hline Mirtazapine & 2 & 30 & 3 & $15-30$ & ol,hal \\
\hline Fluvoxamine & I & 150 & - & - & - \\
\hline Tianeptin & 2 & 37.5 & 2 & 37.5 & flu,pro, \\
\hline Sertraline & 2 & $50-100$ & 2 & 50 & sul,flu \\
\hline Venlafaxine & 2 & $37.5-75$ & 4 & $37.5-150$ & ol,pro \\
\hline Paroxetine & - & - & 4 & $10-40$ & Ol,flu,que \\
\hline Maprotiline & I & 100 & 7 & $50-100$ & zip,ris,flu,hal \\
\hline Fluoxetine & - & - & 3 & $20-40$ & ol,que,zuc \\
\hline escitalopram & - & - & I & 15 & Hal \\
\hline clomipramine & - & - & 3 & 25 & sul,hal \\
\hline
\end{tabular}

AD - antidepressant: map-maprotiline, mir-mirtazapine, ven-venlafaxine, par-paroxetine, fluo-fluoxetine, ser-sertraline, clo-clomipramine, tiatianeptin, esc-escitalopram

AP -antipsychotic: ol-olanzapine, hal-haloperidol, flu-fluophenazine, pro-promazine, sul-sulpiride, que-quetiapine, zip-ziprasidone, ris-risperidone, zuc-zuclopenthixol

vious studies [29]. The other explanation could be the relatively small number of encompassed patients.

Hennessy and al. [4] found that treated schizophrenic patients have longer QTc intervals and higher rates of cardiac arrhythmias than control subjects but they could not determine whether that finding was connected with schizophrenia or its treatment. We found in our study that a great proportion of included patients (more than one third) exceeded the threshold of borderline QTc values (> $450 \mathrm{~ms}$ ) prior to treatment, and the mean duration of psychiatric illness was more than 10 years. Possible explanation for this finding could be that patients with schizophrenia are at higher risk for other illnesses (e.g. atherosclerosis and cardiac abnormalities) than people in the general population $[30,31]$.

\section{Conclusion}

We did not find significant differences in QTc length after two weeks of treatment between patients treated with antipsychotics or antidepressants and those treated with combinations of these drugs. No one patient had QTc interval equal or longer than $500 \mathrm{~ms}$, not before therapy neither after two weeks of therapy, but more than one third of included women had borderline QTc values before starting therapy. Our results encourage us in our clinical work but not in manner to be less cautious when prescribing psychopharmacs, especially in patients with renal, hepatic, cardiovascular or other health problems.

\section{Competing interests}

The author(s) declare that they have no competing interests.

\section{Authors' contributions}

JCS conceived of the study, performed the statistical analysis and helped to draft the manuscript. $\mathrm{VB}, \mathrm{PB}, \mathrm{MH}$ and MSŠ participated in the design of the study and collecting patients for inclusion and helped to draft the manuscript. VJ participated in the design of the study and interpreta- 
Table 3: Characteristics of QTc interval

\begin{tabular}{|c|c|c|c|}
\hline Characteristic & $\begin{array}{c}\text { Group I }(N=32) \\
\text { Patients in monotherapy }\end{array}$ & $\begin{array}{c}\text { Group } 2(N=29) \\
\text { Patients in polytherapy }\end{array}$ & $* \mathbf{p}$ \\
\hline QTc I, mean \pm SD (ms) & $439 \pm 22$ & $439 \pm 22$ & 0.953 \\
\hline QTc II, mean \pm SD (ms) & $439 \pm 24$ & $440 \pm 20$ & 0.878 \\
\hline$* * * \mathbf{p}$ & 0.989 & 0.812 & \\
\hline \multirow[t]{2}{*}{$\mathrm{QTc}$ prolongation, mean $\pm \mathrm{SD}(\mathrm{ms})$} & $8 \pm 17$ & $9 \pm 19$ & 0.840 \\
\hline & & & $* * \mathbf{p}$ \\
\hline QTc I > 450 ms, N (\%) & $12(37.5)$ & $10(34.5)$ & 1.000 \\
\hline QTc II > 450 ms, N (\%) & $10(31.3)$ & $9(31.0)$ & 1.000 \\
\hline QTc | 45 I-470 ms, N (\%) & II (34.4) & $8(27.6)$ & 0.593 \\
\hline QTc II 45 I-470 ms, N (\%) & $6(18.7)$ & $7(24.1)$ & 0.757 \\
\hline QTc I > $470 \mathrm{~ms}, \mathrm{~N}(\%)$ & I (3.1) & $2(6.9)$ & 0.600 \\
\hline QTc II > 470 ms, N (\%) & $4(12.5)$ & $2(6.9)$ & 0.674 \\
\hline QTc II - QTc I > 30 ms, N (\%) & $3(9.4)$ & $3(10.3)$ & 1.000 \\
\hline
\end{tabular}

${ }^{*} \mathrm{p}$ - 2-tailed unpaired $\mathrm{t}$ test; ${ }^{* *} \mathrm{p}$ - 2-tailed Fisher Exact test; ${ }^{* * * *} \mathrm{p}$ - 2-tailed paired $\mathrm{t}$ test; $\mathrm{QTc} \mathrm{I}$ - baseline QTc; QTc II - QTc after two weeks of treatment

tion of data. All authors read and approved the final manuscript.

\section{Acknowledgements}

No acknowledgements.

\section{References}

I. Straus SMJM, Sturkenboom MCJM, Bleumink GS, Dieleman JP, van der Lei J, de Graeff PA, Kingma JH, Stricker BHCh: Non-cardiac QTcprolonging drugs and the risk of sudden cardiac death. European Heartjournal 2005, 26:2007-20I2.

2. Straus SMJM, Bleumink GS, Dieleman JP, van der Lei J, 't Jong GE, Kingma JH, Sturkenboom MCJM, Stricker BHCh: Antipsychotic and the risk of sudden cardiac death. Arch Intern Med 2004, 164: 1293-I 297.

3. Gardner DM, Baldessarini RJ, Waraich P: Modern antipsychotic drugs: A critical overview. CMAJ 2005, 172: I703-I7II.

4. Hennessy S, Bilker WB, Knauss JS, Margolis DJ, Kimmel SE, Reynolds RF, Glasser DB, Morrison MF, Strom BL: Cardiac arrest and ventricular arrhythmia in patients taking antipsychotic drugs: cohort study using administrative data. BMJ 2002, 325: 1070-1074.

5. Fayek M, Kingsbury SJ, Zada J, Simpson GM: Cardiac effects of antipsychotic medications. Psychiatr Serv 200I, 52:607-609.

6. Vieweg WVR, Wood MA: Tricyclic antidepressants, $\mathbf{Q T}$ interval prolongation and torsade de pointes. Psychosomatics 2004, 45:37I-377.

7. Glassman AH, Bigger JT: Antipsychotic drugs: prolonged QTc interval, torsade de pointes, and sudden death. Am J Psychiatry 200I, I 58: I774-1782.

8. Drew BJ, Califf RM, Funk M, Kaufman ES, Krucoff MV, Laks MM, Macfarlane PV, Sommargren C, Swiryn S, Van Hare GF: Practice standards for electrocardiographic monitoring in hospital settings. Circulation 2004, I 1 0:2721-2746.

9. Committee for Medicinal Products for Human Use: The Clinical Evaluation of QT/QTc Interval Prolongation and Proarrhythmic Potential for Non-Antiarrhythmic Drugs. 2004 [http://www.emea.eu.int/pdfs/human/ich/000204en.pdf.].

10. Cheng J: Evidences of the gender-related differences in cardiac repolarization and the underlying mechanisms in different animal species and human. Fundam Clin Pharmacol 2006, 20:1-8.

11. Pham TV, Rosen MR: Sex, hormones, and repolarization. Cardiovasc Res 2002, 53:740-75I.
12. Drici M-D: Influence of gender on drug-acquired long QT syndrome. Eur Heart J Supplements 200I, 3(Suppl K):K4I-K47.

13. Ito $\mathrm{H}$, Kono $\mathrm{T}$, Ishida $\mathrm{S}$, Maeda $\mathrm{H}$ : Gender difference in QTc prolongation of people with mental disorders. Ann Gen Hosp Psychiatry 2004, 3:3.

14. Van Mieghem C, Sabbe M, Knockaert D: The clinical value of the ECG in noncardiac conditions. CHEST 2004, I 25: I56 I-I 1576.

15. Llerena A, Berecz R, Dorado P, De la Rubia A: QTc interval, CYP2D6 and CYP2C9 genotypes and risperidone plasma concentrations. J Psychopharmacol 2004, 18:189-193.

16. O'Brien P, Oyebode F: Psychotropic medication and the heart. Adv Psychiatr Treat 2003, 9:414-423.

17. Moss AJ: Long QT syndrome. JAMA 2003, 289:204I-2044.

18. Kass RS, Moss AJ: Long QT syndrome: novel insights into the mechanisms of cardiac arrhythmias. I Clin Invest 2003, I | 2:8|0-8|5.

19. Moss AJ, Kass RS: Long QT syndrome: from channels to cardiac arrhythmias. J Clin Invest 2005, I I 5:2018-2024.

20. Clancy $c E$, Kass RS: Inherited and acquired vulnerability to ventricular arrhythmias: cardiac $\mathbf{N a}+$ and $\mathrm{K}+$ channels. Physiol Rev 2005, 85:33-47.

21. Priori SG: Inherited Arrhythmogenic Disease: The complexity beyond monogenic disorders (reviews). Circ Res 2004, 94: $140-145$.

22. Roden DM, Viswanathan PC: Genetics of acquired long QT syndrome. I Clin Invest 2005, I I 5:2025-2032.

23. Yang P, Kanki H, Drolet B, Yang T, Wei J, Viswanathan PC, Hohnloser SH, Shimizu W, Schwartz PJ, Stanton M, Murray KT, Norris K, George AL, Roden DM: Allelic variants in long-QT disease genes in patients with drug-associated torsades de pointes. Circulation 2002, 105:1943-1948.

24. Mitcheson JS, Chen J, Lin M, Culberson C, Sanguinetti MC: A structural basis for drug-induced long QT syndrome. PNAS 2000, 97:12329-12333.

25. Arizona CERT: Drug List by Risk Groups. [http://www.arizonac ert.org/medical-pros/drug-lists/drug-lists.htm].

26. Sala M, Vicentini A, Brambilla P, Montomoli C, Jogia JRS, Caverzasi E, Bonzano A, Piccinelli M, Barale F, de Ferrari GM: QT interval prolongation related to psychoactive drug treatment: a comparison of monotherapy versus polytherapy. Ann Gen Psychiatry 2005, 4: 1

27. WHO: Collaborating Centre for Drug Statistics Methodology; ATC Index with DDDs 2006. 2005 [http://www.whocc.nol atcddd/]. 
28. Al-Khatib SM, Allen LaPointe NM, Kramer JM, Califf RM: What clinicians should know about the QT interval. JAMA 2003, 289:2I 20-2I 27 .

29. Rijcken CAW, Monster TBM, Brouwers JRBJ, de Jong-van den Berg LTW: Chlorpromazine equivalents versus defined daily doses: how to compare antipsychotic drug dosed? J Clin Psychopharmacol 2003, 23:657-659.

30. Haverkamp W, Breithardt G: Drug-induced sudden cardiac death. Eur Heart J 2005, 26:1808-1809.

31. Shah SU, lqbal Z, White A, White S: Heart and mind: psychotropic and cardiovascular therapeutics. Postgrad Med J 2005, 8I:33-40.

Publish with Bio Med Central and every scientist can read your work free of charge

"BioMed Central will be the most significant development for disseminating the results of biomedical research in our lifetime. "

Sir Paul Nurse, Cancer Research UK

Your research papers will be:

- available free of charge to the entire biomedical community

- peer reviewed and published immediately upon acceptance

- cited in PubMed and archived on PubMed Central

- yours - you keep the copyright

Submit your manuscript here:

http://www.biomedcentral.com/info/publishing_adv.asp 